\title{
Designing a knowledge based technology transfer model using the fourth generation
} approach in the automotive industry

\section{Mansour Sabeti}

PHD student in Azad University South Branch,

Islamic Azad University, South Tehran Branch, Tehran, Iran, República Islâmica do Irã sabeti.mansour@gmail.com https://orcid.org/0000-0002-5671-1827

Gholam reza Hashemzadeh Faculty Member of Islamic Azad University - South Branch, Tehran, Iran República Islâmica do Irã hashemzadeh_gh@yahoo.com

Parvaneh Gelard

Assistant Professor and faculty member of management at Islamic Azad University South Tehran Branch P_gelard@yahoo.com https://orcid.org/0000-0001-8421-1582

Mahnaz Rabiei

Professor at Islamic Azad University - South Tehran Branch

República Islâmica do Irã dr_mahnaz_rabiei@azad.ac.ir https://orcid.org/0000 0001-5682-2730

\begin{tabular}{|c|} 
Editor Científico: José Edson Lara \\
Organização Comitê Científico \\
Double Blind Review pelo SEER/OJS \\
Recebido em 16.07.2019 \\
Aprovado em 25.03.2020
\end{tabular}

\footnotetext{
Este trabalho foi licenciado com uma Licença Creative Commons - Atribuição - Não Comercial 3.0 Brasil
} 


\begin{abstract}
Technology transfer is a process involving diverse and complex dimensions as an effective tool to reduce the technological gap between developed and developing countries. Over the last century, technology futurism has gone through three eras and is now entering its fourth generation. In the first generation the content of technology forecasting focused on hard technologies, the second generation focused on the combination of hard technology and the market, and the third generation focused on the future of hard technology and integrating social and economic dimensions. In the fourth generation, the emphasis has been on soft technologies, hard technologies, integration of economic, social, political and environmental dimensions as effective factors in technology transfer. The process of technology transfer in the Iranian automobile industry has been limited to the introduction of a set of machinery, maps, catalogs and guidelines. Based on the fuzzy Delphi method, a model has been developed for the transfer of knowledge-based technologies in the automotive industry with a fourth generation technology futuristic approach.
\end{abstract}

Keywords: Soft Technology; 4th Generation Technology Forecasting; Technology Transfer; Knowledge Based Technology; Automotive Industry

\title{
Projetando um modelo de transferência de tecnologia baseada no conhecimento utilizando a abordagem da quarta geração na indústria automotiva
}

\section{Resumo}

A transferência de tecnologia é um processo que envolve dimensões diversas e complexas como uma ferramenta eficaz para reduzir o fosso tecnológico entre países desenvolvidos e em desenvolvimento. Ao longo do século passado, o futurismo tecnológico passou por três épocas e agora está entrando em sua quarta geração. Na primeira geração, o conteúdo da previsão de tecnologia se concentrou em tecnologias rígidas, a segunda geração se concentrou na combinação de tecnologia rígida e no mercado e a terceira geração se concentrou no futuro da tecnologia rígida e na integração de dimensões sociais e econômicas. Na quarta geração, a ênfase tem sido em tecnologias leves, tecnologias duras, integração de dimensões econômicas, sociais, políticas e ambientais como fatores efetivos na transferência de tecnologia. O processo de transferência de tecnologia na indústria automobilística iraniana foi limitado à introdução de um conjunto de máquinas, mapas, catálogos e diretrizes. E baseado no método difuso Delphi, um modelo foi desenvolvido para a transferência de tecnologias baseadas no conhecimento na indústria automotiva, com uma abordagem futurista de quarta geração em tecnologia.

Palavras-chave: Soft Technology; Previsão de Tecnologia de $4^{a}$ Geração; Transferência de tecnologia; Tecnologia baseada no conhecimento; Indústria automobilística

\section{Introduction}

Today, the automobile industry in the country accounts for a large portion of employment, per capita production and industrial value added, and accounts for a significant share of national gross income. Peter Drucker calls the automotive industry the industry and refers to it as the 
mother of industries. Important industries that are closely related to the automotive industry include steel, aluminum, copper, glass, rubber, textile, electronics, paint and chemicals, which are regarded as the upstream industries of the automotive industry. In fact, the automotive industry is a symbolic figure in the economic and industrial development of a country, and its operations range from production to distribution, consumption and after-sales services. As the automotive and technology industries are rapidly changing, the industry will need to keep pace with these developments by exploiting appropriate approaches to effectively transfer technology, particularly through FDI and joint venture partnerships.

The world-renowned JV maintains and upgrades its industrial presence. The production of an average of one and a half hundred thousand automobiles annually in the country and employs about 50,000 direct people in this industry and one million indirectly demonstrates the importance of this industry for economic and technical growth and development of the country. But the industry's past and present study shows that despite efforts to effectively transfer technology and achieve relative standards in achieving domestic customer satisfaction, penetrating global markets, designing new products, and competing with other leading countries The automotive industry still faces many challenges (Research project of the Parliamentary Studies Center in the automotive industry, January 2015). In line with the goals of the Islamic Republic of Iran's vision document in Horizon 1404, with emphasis on software development and the production of science and achieving prime economic, scientific and technological status at the regional level (Central and Southwest Asia), the automotive industry as a pioneer and driving force The country's industry can contribute to the country's prospects through the creation of scientific, technical and other capabilities.

Accordingly, the outlook for the automotive industry is as follows: achieving first place in the region's auto industry, fifth in Asia and 11th in the world, and through technology-based competitiveness. It is not possible to reach the outlook of 1404 countries and produce 3 million vehicles, one million of which are export share, with national conditions and current models of cooperation with other automakers and the current status of Iranian automakers, according to industry experts. It has been proposed to provide a suitable model for the transfer of knowledgebased technologies in the automotive industry with a fourth-generation approach to technology futures as well as previous generations in order to provide a clear horizon for decision makers and managers in the industry. 


\section{Theoretical foundations:}

\subsection{The concept of knowledge-based technology}

Knowledge-based technology Technology is said to enhance the science of wealth, knowledge-based economic development and the realization of scientific and economic goals in one direction (the invention and innovation), and ultimately the commercialization of $R \& D$ results (including product design and production), And services (in modern scientific and industrial fields). (Knowledge Base Companies and Institutions Regulations, 2017)

\subsection{Knowledge-based technologies in the automotive industry}

\subsection{1- Clean fuel technologies in cars}

All over the world safety, environment and price are the top priority for manufacturers. A number of knowledge-based technologies in the automotive industry are mentioned.

- Polymer tanks: Fuel tanks are traditionally metallic but have been replaced in recent years by polymer tanks. These buckets are lighter in weight and the energy used to produce them is 30 percent lower than traditional buckets. Due to the role of polymer tanks in reducing vehicle weight, fuel consumption is reduced and their emissions are reduced;

- Fuel Leakage Alert: A fuel leakage monitoring and warning system is one of the most important systems that can be effective in reducing vehicle fuel loss. These systems are fitted to most cars around the world and alert gasoline and vapors out of the tank if they leak;

- Gas or gasoline base: Technically, gasoline-powered cars increase fuel consumption and emissions. Because the fuel system of these cars is designed for gasoline and is not compatible with other fuels. To avoid this problem, one should use gas-fired vehicles that are gas-based;

- ORVR System: This system does not leak fuel from the tank when the fuel vapor is refueled. As a result, air pollution is significantly reduced;

- Auto Refueling System: Equipping fuel distribution stations with automated and protected fueling systems that prevent gasoline vapors from leaving;

- In-car nanotechnology: The use of nanotechnology-based soot filters can prevent the city from becoming more polluted. These types of filters can absorb fine particles and prevent them from entering the air; 
- Fuel Catalytic Converter Fuel catalyst converter is one of the systems composed of elements like platinum, palladium, rhodium, iron, manganese, nickel and copper. This converter can convert a significant portion of the exhaust pollutants into inert gases, water and carbon dioxide;

- Canister system: It is the duty of the canister to prevent fuel vapor from entering the air when the vehicle is off. The system pulls gasoline into the engine when the engine is turned on to burn, but when the engine is turned off, the vapors in the carbon-activated tank can be neutralized to prevent contamination.

Other technologies:

- V2V technology: Imagine you are approaching a crossroad and at the same time no other car is paying attention to the red light. You may not be able to see the car in the first place, but your car will receive a signal from another car indicating it is on your way, warning of a potential accident or even automatically braking to prevent it Accident;

- Automatically Automobiles: A real automobile has many capabilities and can move in addition to the park automatically. These cars can access information about environments faster than humans through lasers, radars and cameras. Analyze and evaluate the environment;

- Virtual reality dashboards: Cars can detect external objects in the path and display information about them on the windshield. Virtual reality dashboards have the same functionality as robots;

- Energy storage panels: Panels that are mounted on the body and can store energy and charge faster than today's batteries. For mounting on the body and have the flexibility to weld;

- Electronic communication with the car via mobile: such as vehicle control for turning on and off, fuel and tire pressure control, car warm-up on cold days, inability to use the vehicle for minors, vehicle tracker to prevent theft Car, cruise control and the like are possible with electronic communication.

\subsection{Technology Forecasting}


Forecasting aims to present effective strategies for the present, explaining the challenging vision of the future. Future projects are carried out with the following objectives:

- Identify potential opportunities for the economy or society through new technologies;

- Knowledge How to tackle key community challenges with the help of future knowledge and technologies;

- Technology futurism provides an input to systematize policies and strategies. In addition, foresight in technology supports creativity and motivation and helps people in technology and technology transfer to achieve effective competition and development. Nowadays, especially in the field of science and technology, due to the development and evolution of its concepts and methods, it has become an important tool for decision making, policy making and strategic planning. (UNIDO Technology Futures Guide, Sonia Shafiei Ardestani, 2008).

Table 1 - Comprehensive Technology Futures (Geoing Jin, 2016)

\begin{tabular}{|l|c|l|}
\hline \multicolumn{1}{|c|}{ Content } & Time period & \multicolumn{1}{c|}{ Stage and features } \\
\hline The first generation & $\begin{array}{c}\text { the 1920s and 1930s and } \\
\text { after World War I }\end{array}$ & predicts the hard technologies \\
\hline The second generation & 1960s decade & Hard technology combined with the market \\
\hline The third generation & 1990s decade & $\begin{array}{l}\text { focuses on the future of hard technology and integrates the } \\
\text { social, economic and environmental dimensions }\end{array}$ \\
\hline The fourth generation & After 2000 & $\begin{array}{l}\text { futurism in both soft and hard technologies, integrating } \\
\text { different social, economic and environmental dimensions }\end{array}$ \\
\hline
\end{tabular}

\subsection{Soft technology}

Soft technology shapes the rules, mechanisms, tools, rules, methods, and procedures that contribute to the development, adaptation, or control of the subjective and objective human world. Soft technology considers internal psychological activities and external behaviors of human beings as their operational subject and its content and levels are determined by focusing on the modes of thinking and modes of action of human beings. (Mehdi Hamzepour, 2018)

Soft technology is the technology of thought that is central to human beings and is the result of innovations created through the system of values, individual behavior, organizational behavior, and social behavior. In firms with higher levels of technology complexity, naturally, the impact of soft technologies, such as human focus and human resources, is becoming more pronounced. (Manouchehr Manteghi, 2017) 


\subsection{Technology Transfer Models:}

Technology transfer is considered an active process in which technology is transferred from one border to another. UNIDO has defined the innovative transfer of technology through the development of technological capabilities through the transfer of technology that has led to increased innovation capability. In the field of technology transfer, there are various models that each have a particular perspective on the transfer. Each of these models contains criteria that influence the choice of transmission methods. Although similar criteria may exist in these models, in general each of these models contains criteria that are different from the other models. By studying different models of technology transfer such as Fall, Tenkasi and Mehraman, Johnson Foster, Raten and Hiyami models, Malik and others identified that the process of technology transfer in general and from the identification, selection, absorption, application and dissemination sectors. Technology is formed.

\subsection{Studies on Technology Transfer Management Process and Futures:}

Table 2 - Results of studies on technology transfer management

\begin{tabular}{|c|c|c|c|}
\hline Row & Researcher & $\begin{array}{c}\text { Yea } \\
\mathbf{r}\end{array}$ & Content \\
\hline 1 & $\begin{array}{l}\text { James } \\
\text { Koningham }\end{array}$ & 2018 & $\begin{array}{l}\text { In addition to policy making and processes, one should consider this process } \\
\text { from the macro, meso and micro angles in order to transfer appropriate } \\
\text { technology. In other words, the role of actors such as technology transfer staff, } \\
\text { universities, professional research organizations, technology departments and } \\
\text { scientists was considered. }\end{array}$ \\
\hline 2 & $\begin{array}{l}\text { Johan Scott \& } \\
\text { Edward } \\
\text { Steinmuller }\end{array}$ & 2018 & $\begin{array}{l}\text { Three Frameworks for Innovation Policy are recognized, being the first } \\
\text { government-sponsored framework for science and research and development } \\
\text { to support market growth and support market failure in delivering new } \\
\text { knowledge privately. Slow. The second framework in the world of the 1980s } \\
\text { is its emphasis on the competition created by national innovation systems for } \\
\text { knowledge creation and commercialization. The above policy focuses on } \\
\text { establishing communications, clusters and networks and stimulating } \\
\text { education. The third framework has been identified with contemporary social } \\
\text { and environmental challenges such as the Sustainable Development Goals and } \\
\text { the demand for change and transformation and has been distinguished from } \\
\text { the two primary frameworks that refer to the socio-technical system. }\end{array}$ \\
\hline 3 & $\begin{array}{l}\text { Anika Lorenz, } \\
\text { Michael Raven, } \\
\text { and Kenneth } \\
\text { Blaine }\end{array}$ & 2017 & $\begin{array}{l}\text { The role of standardization as a vital and vital mechanism for technology } \\
\text { transfer tools is of particular importance. }\end{array}$ \\
\hline 4 & $\begin{array}{l}\text { Adam } \\
\text { Mazorkiewicz } \\
\text { and Beata } \\
\text { Potralska }\end{array}$ & 2017 & $\begin{array}{l}\text { The obstacles and challenges of technology transfer in research and } \\
\text { development organizations fall into three groups of technical, organizational } \\
\text { and systemic barriers that must be properly identified and addressed during } \\
\text { technology transfer. }\end{array}$ \\
\hline 5 & $\begin{array}{l}\text { Cheryl Martin } \\
\text { \& Helena } \\
\text { Laurent }\end{array}$ & 2017 & $\begin{array}{l}\text { Environmental concerns are evident in all the innovations and initiatives. } \\
\text { Therefore, the issue of environment and its special role in technology transfer } \\
\text { should be considered. }\end{array}$ \\
\hline
\end{tabular}




\begin{tabular}{|c|c|c|c|}
\hline 6 & $\begin{array}{l}\text { Sumon } \\
\text { Takakova \& } \\
\text { Iwika Waza }\end{array}$ & 2014 & $\begin{array}{l}\text { Structural changes in the world economy, product architecture, information } \\
\text { technology, research and development, intellectual property rights, human } \\
\text { resource management and organizational communication are important } \\
\text { factors in the competitive environment and important in the transfer of } \\
\text { technologies. }\end{array}$ \\
\hline 7 & Xiaoying Jun & 2013 & $\begin{array}{l}\text { Technology Transfer in China's Automotive Industry has been examined, } \\
\text { including government policies in the automotive industry, Chinese } \\
\text { companies' over-reliance on R\&D and technology transfer to foreign } \\
\text { companies, foreign direct investment, environmental impacts. Has pointed to } \\
\text { clean energy technology and proper fuel consumption, the knowledge base of } \\
\text { local engineers with skills training and development. }\end{array}$ \\
\hline 8 & $\begin{array}{l}\text { Ali Mosleh } \\
\text { Shirazi, Ali } \\
\text { Mohammadi, } \\
\text { Abbas Abbasi }\end{array}$ & 2016 & $\begin{array}{l}\text { Soft technology as a new paradigm in technology transfer is effective. Soft } \\
\text { technology comprises production optimization literature and business } \\
\text { services (lean manufacturing, comprehensive quality management, ISO, } \\
\text { Kanban, human resources planning, global trade name, marketing, etc.) which } \\
\text { favors greater competition in the organization. It is also a prerequisite for the } \\
\text { survival of economic companies in a competitive environment. }\end{array}$ \\
\hline 9 & $\begin{array}{l}\text { Mahmoud } \\
\text { Samiee Nasr, } \\
\text { Parivash Jafari }\end{array}$ & 2012 & $\begin{array}{l}\text { The components of successful technology transfer have been extracted and } \\
\text { presented a general model of effective technology transfer in the automotive } \\
\text { industry. These components include macro-environmental factors, transition } \\
\text { process, communications, research and development, foreign direct } \\
\text { investment, joint ventures, innovation and technology transfer center. }\end{array}$ \\
\hline 10 & $\begin{array}{l}\text { Mojgan } \\
\text { Marashi, Neda } \\
\text { Abdolvand }\end{array}$ & 2018 & $\begin{array}{l}\text { Technology transfer governance jointly refers to the role of government, } \\
\text { effective policymaking, protocols, and management frameworks, a network } \\
\text { of people involved, communications, contracts, knowledge, and human } \\
\text { resources. }\end{array}$ \\
\hline 11 & $\begin{array}{l}\text { Hojat Ashouri, } \\
\text { Seyed } \\
\text { Mohammad } \\
\text { Seyyed } \\
\text { Hosseini, Reza } \\
\quad \text { Radfar } \\
\end{array}$ & 2017 & $\begin{array}{l}\text { Indicators and Factors Influencing Technology Transfer in High Speed Train } \\
\text { Industry At each stage of the technology transfer process are identified and on } \\
\text { training, documentation, design and deployment of management systems and } \\
\text { structures, forecasting Graphics, technology life cycle curve analysis, industry } \\
\text { relationship with major universities are mentioned in this article. }\end{array}$ \\
\hline 12 & $\begin{array}{l}\text { Morteza } \\
\text { Moosseini, } \\
\text { Davood } \\
\text { Gharakhani }\end{array}$ & 2013 & $\begin{array}{l}\text { Factors affecting technology transfer have been identified and ranked. } \\
\text { Identified factors include product life cycle, government policies, culture, } \\
\text { research and development, education and communication. }\end{array}$ \\
\hline
\end{tabular}

\subsection{Comparative Comparison of Car Production Status in China, Turkey, India and Iran}

In order to draw a detailed understanding of the status of the automobile industry in the world, this study aimed to compare the policies used in some countries such as China, India, Turkey and the policies and methods used in the Iranian automotive industry. Let's compare the differences between the policies and the resulting output numbers so that we can provide a more complete model with this information. China, India, and Turkey, as they have achieved widespread and quantitative success in the automotive industry for many years, appear to be better suited to Iran than the elite view of the industry.

Table 3 - Comparative Comparison of Car Production Status in Selected Countries 


\begin{tabular}{|c|c|c|c|}
\hline $\begin{array}{l}\text { Country } \\
\text { name }\end{array}$ & Policies $^{1}$ & $\begin{array}{c}2017 \\
{ }^{2} \text { Production }\end{array}$ & $\begin{array}{l}2018 \\
\text { Production }\end{array}$ \\
\hline CHINA & $\begin{array}{l}\text { - Contribute to the domestic market by focusing on } \\
\text { delivering quality product } \\
\text { - } \quad \text { Joint venture with the world's top automakers } \\
\text { Technology transfer through the hiring of external } \\
\text { experts } \\
\text { - Strengthening the production, sales and after-sales } \\
\text { service } \\
\text { - } \quad \text { Boops \& Investing in R\&D } \\
\text { Buying famous or bankrupt companies and utilizing } \\
\text { their specialized power } \\
\text { Export Promotion Policy }\end{array}$ & 29.015 .434 & 27.809.196 \\
\hline INDIA & $\begin{array}{l}\text { - Buy some car companies like Sang Young in South } \\
\text { Korea } \\
\text { - Buying some car design companies like Pinin Farrina, } \\
\text { Italy } \\
\text { - Mutual cooperation of Indian automakers like } \\
\text { Mahindra with foreign companies } \\
\text { Focusing on the domestic market due to the abundance } \\
\text { of the middle class of the car applicant } \\
\text { Achieve advantage in the software world and } \\
\text { subsequently penetrate the automotive industry } \\
\text { Moving towards the production of all electric vehicles } \\
\text { by } 2030\end{array}$ & 4.782.896 & 5.174 .645 \\
\hline TURKEY & $\begin{array}{l}\text { - The highest level of integration in the automotive } \\
\text { industry in the world } \\
\text { - Joint venture with the world's top automakers } \\
\text { - Investing in R\&D } \\
\text { - Export and Import }\end{array}$ & 1.695.731 & 1.550 .150 \\
\hline IRAN & $\begin{array}{l}\text { - Partnering with some European companies such as } \\
\text { Renault, Peugeot and Citroen France } \\
\text { - Change of partner country from France to China after } \\
\text { the first round of sanctions in } 2012\end{array}$ & 1.515.396 & 1.095.526 \\
\hline
\end{tabular}

\footnotetext{
Information Reference This column is drawn from the Sappco Company's Strategic Studies and Planning Reports and the Department of Infrastructure Research and Production Reports.
}

${ }^{2}$ Production statistics are from the www.OICA.net site. 
- National car production and emphasis on vehicle circulation

\section{Proposed Conceptual Model of Technology Transfer with Fourth Generation Approach to Technology Futurism}

To design and present a conceptual model by summarizing comparative studies in the automotive industry of China, India, Turkey, and summarize the key points that these countries matter to, and in particular each of the factors in the fourth generation technology futures model. We've included it. Also, the opinions gathered from the automotive industry elite who had a management background in the industry and had the majority of the average twenty years experience with high engineering experience and education were also used in model design. From the studies on the process of technology transfer management referred to in Table 3, the most important were selected and included in each of the parameters of the fourth generation model.

The proposed model considers the macro factors of soft and hard foresight technology as the model shell. In other words, in order to transfer the knowledge base technology of the automotive industry in Iran, one must first address the futuristic concepts of soft and hard knowledge base technology referred to in the preceding pages, and after this has been explored, then enter the second set of factors including factors. It became political, economic, social and environmental. Each of these factors includes the following factors that are mentioned in the tables below. 
Tables 4 - Factors and Sub-Factors of the Fourth Generation Model of Technology Futures

\begin{tabular}{|l|c||lc||}
\hline \multicolumn{1}{|c||}{ Soft Technology Foresighting } & Code & Hard Technology Foresighting & Code \\
\hline Creativity and Innovation & A1 & Machinery & B1 \\
\hline Research and development & A2 & Tools & B3 \\
\hline $\begin{array}{l}\text { Industry Relationship with University and } \\
\text { Knowledge Based Institutions }\end{array}$ & A3 & Hardware \& Computers & B4 \\
\hline Know how and knowledge & A6 & & A5 \\
\hline $\begin{array}{l}\text { Management systems } \\
\text { Experiences, training life cycle }\end{array}$ & A7 & \\
\hline \begin{tabular}{l} 
Processes and Systems \\
\hline
\end{tabular}
\end{tabular}

\begin{tabular}{|l|c||l||c||}
\hline \multicolumn{1}{|c|}{ Political Factors } & Code & \multicolumn{1}{|||}{ Economic Factors } & Code \\
\hline Political relations with countries & C1 & Foreign direct investment & D1 \\
\hline Conditions of sanctions & C2 & $\begin{array}{l}\text { Policies (export development, } \\
\text { import substitution, etc.) }\end{array}$ & D3 \\
\hline Conditions of war risk & C3 & $\begin{array}{l}\text { Structural changes in the world } \\
\text { economy and Iran }\end{array}$ & D4 \\
\hline Technology transfer tendency & C4 & Effective government support & D5 \\
\hline
\end{tabular}

\begin{tabular}{|l|c||c||c||}
\hline \multicolumn{1}{|c|}{ Social Factors } & Code & Environmental Factors & Code \\
\hline Human capital & E1 & Environmental challenges & F1 \\
\hline National and organizational culture & E2 & Energy consumption & F2 \\
\hline Social challenges & E3 & & \\
\hline Intellectual Property Rights & E4 & & \\
\hline
\end{tabular}




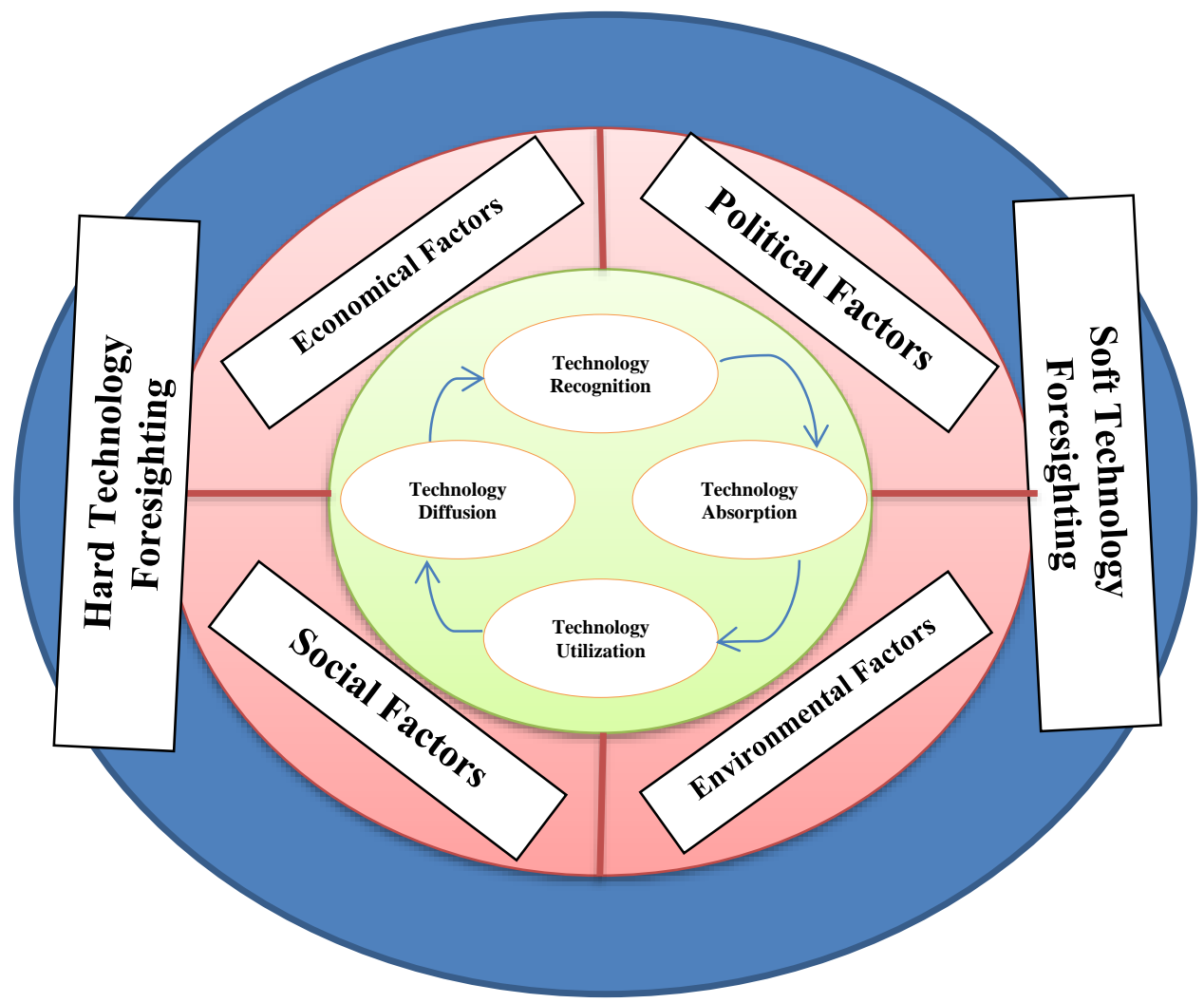

Figure 2- presents the proposed model.

Proposed research model

In the proposed model, each of the political, economic, social and environmental factors is identified using library studies and expert opinions and effective parameters are identified. It is also designed based on the technology futurism of this model, which has been identified as a very important predictor and futurist. Whereas technology futurism has been emphasized as an important point of the fourth generation.

In Figure Two we show Proposed Conceptual Model of Knowledge Technology Transfer with Fourth Generation Technology Futures Approach.

The proposed model has features that have been developed based on the fourth generation of technology futures and library studies and the opinions of automotive experts. The following table presents the features of the proposed model. 
Table 5 - Properties of Proposed Technology Transfer Model

\begin{tabular}{|c|l|}
\hline Row & \multicolumn{1}{|c|}{ Properties of the proposed model } \\
\hline 1 & Emphasis on Soft Technology \\
\hline 2 & Emphasizing the integration of economic, political, social and environmental dimensions \\
\hline 3 & Emphasis on Technology Futurism \\
\hline 4 & $\begin{array}{l}\text { Identifying the effective factors in each of the effective dimensions through the Iranian automotive } \\
\text { industry elite }\end{array}$ \\
\hline 5 & Identifying knowledge-based technologies and innovations in the future of the automotive industry \\
\hline 6 & Comparative Comparison of Leading Countries in the Automotive Industry \\
\hline
\end{tabular}

\section{1- Introducing the extracted factors and sub-factors:}

In the following, we will introduce the above mentioned factors and sub-factors and try to present comprehensive and comprehensive concepts of each.

\section{A) Soft Technology Foresighting:}

A1) Creativity and Innovation: Creativity is a thought process that leads to the production of ideas. Creativity is the use of imagination and imagination to create a new thought or concept. Innovation is the implementation of new ideas and ideas that originate from creativity. In fact, creativity innovation has been implemented. Creativity and innovation do not have the same meaning. Creativity is called the production of new and lean ideas, while innovation refers to the application of the idea, if we consider the idea as a "seed," a plant innovation that comes from the planting and cultivation of an idea seed. In innovation, value is added to the idea without which the idea remains merely a raw idea, no more. Creativity requires innovation. When an idea is put into practice, it is no longer creativity, but innovation.

A2) Research and Development: According to the Organization for Economic Cooperation and Development, research and development is called "creative work that is systematically done to add to existing knowledge and apply this knowledge to invent new applications".

\section{A3) Industry Relationship with University and Knowledge Based Institutions:} University-industry collaboration is an important component of countries' knowledge-based development, and in most developed countries the root of academic growth in universities can be focused on close cooperation with industries and vice versa, development. An industry in a 
competitive environment attributed to having a purposeful and demand-driven relationship with industries. (Gilan Niknejad; Akbar Akbari; Afsaneh Shahabi and Parvin Taherifar).

A4) Technical Knowledge: A term used to express practical knowledge of how to do something. Trick or technical knowledge usually includes tacit knowledge that is the opposite of explicit knowledge. Technical knowledge describes how to do a task that relates to the skills or ability to perform a particular activity.

A5) Management Systems: Over the past few decades, management tools have become an important part of the lives of organization leaders. Organizational leaders strive every day to increase revenue, innovate, improve quality, plan for the future, and so on using management tools. Systems such as the Renault SPR, Nissan NPMS, and more ...

A6) Experiences, training and knowledge management: Technical skills are acquired through education, training and experience. Gain experience in the workplace and record it with knowledge management and by providing stakeholders, carpentry training, OJT, scheduled training for various organizational levels, and science and technology education all along the way. Increasing technical skill and knowledge are effective.

Knowledge management means making systematically available information and scientific resources available to those in need so that they can do their day-to-day work more efficiently and effectively.

A7) Processes and Systems: Thomas Davenpor (1992) considers business processes as a set of activities that are logically linked and performed to achieve a specific achievement in business. Processes have two important characteristics: First, each process has customers (or customers) who are given (or benefit from) the output of the process. These customers can be in-house or out-of-company, and systems fall under all the categories used in product lines, including instructions, operating procedures and operations flow (SOS).

\section{B) Hard Tech Foresighting:}

B1) Machinery: A tool consisting of one or more components that uses energy to perform the desired job. In the automotive industry, all robots, cranes, guns, cannons, machinery for transporting materials and products, and so on are all part of the machinery industry.

B2) Tools: A tool is a device used to produce something or do something that is not consumed during the production process. Simply put, a tool can be a process or process used to 
achieve a specific goal. Tools used in the automotive industry include measuring and testing tools, instrumentation, wind, pneumatic, general, workshop and repair equipment, turning, welding, electrical equipment, high pressure, and so on.

B3) Hardware and Computers, IT: All equipment and hardware used in production lines that are involved in the manufacturing process from the stage of manufacturing parts, bodywork, paint and assembly to PLCs, modules, hardware used in production lines. Like Pocket PCs, industrial computers, controls and industrial automation are exploited.

B4) Product Life Cycle: The product life cycle is the rate of progression of one step to four stages in the market life. The four stages of the life cycle are defined as: introduction (emergence), growth, maturity, and decline. Each product has a life cycle and the time elapsed in each step varies from product to product.

\section{C) Political factors:}

C1) Political Relations with Countries: Due to the specific political situation of Iran in the Middle East region, in some cases, such as export or joint venture, political relations with other countries should be given special attention.

C2) Sanctions: The Islamic Republic of Iran has always been involved in sanctions because of hostile policies by arrogant countries such as the United States. This makes the technology transfer particularly special and technology owners are less interested in transferring technology to Iran. The post-bribery conditions provided a good basis for technology transfer and contracting with developed countries, and virtually all of these communications were discontinued with the US withdrawal. (Renault, Peugeot, Citroen and Berlins exit the production cycle)

C3) Conditions of war risk: The shadow of the war has led to less direct foreign investment as well as private domestic investment due to the hostile US policies.

C4) Technology Transfer Desire: Technology-savvy countries are less inclined to transfer technology to some countries, such as Iran. Some of these factors are due to political and security issues, and it is sometimes observed that the transfer of technology through the dual use of military-industrial technology makes the technology transfer or less reluctant to do so.

\section{D) Economic factors:}


D1) Foreign Direct Investment (FDI): According to the UN Conference on Trade and Development (ANCAD), it is the creation and acquisition of sustainable benefits for national legal and natural persons in an economic activity (corporation shareholding). ..) In another country, such enduring interests imply a long-term relationship between direct investment on the one hand and the subject of investment on the other.

D2) Policies (export promotion, import substitution, etc.): Transparency of the type of policy making in a country's economy will be a clear signal to investors and industrialists. Import substitution policies or export expansion policies, depending on their choice, will influence the decisions of investors and craftsmen.

D3) Structural changes in the world economy and Iran: The world economy has undergone wide changes in financial and economic balance in the face of the emergence of new industrial and service giants such as China and India. Technological change and the advent of the information age and the expansion of communication networks have had a significant impact on the workforce and the world economy. Also in the Iranian economy are exchange rate changes, national currency devaluation, sanctions and economic growth, stagnation and inflation. Economic instability, government influence, and private companies in various sectors of the industry are important issues in the structural changes of the Iranian economy. (Shokouh al-Sadat Seyed Ali Akbar, 2016)

D4) Effective Government Support: Government support for industries will increase production growth rates and reduce unemployment. Such as providing needed currency for industries, paying working capital facilities to producers, tax exemptions for producers, establishing appropriate laws to support industries such as import tariffs and incentives for final export of automotive product and parts, ease of importing raw materials. And customs assistance is something governments can have to effectively protect the industry. (Special Package of Government Support for Industry, 1977)

D5) Market and Customer Attention: The market is a place that meets the potential needs of buyers as well as sellers. The market may be physical or virtual, or local or global. (Philip Cutler, 2010) 


\section{E) Social factors:}

E1) Human Capital: Human capital is a set of characteristics, life experiences, knowledge, creativity, innovation and energy that individuals exploit in their work. (Leslie Werley, 2003)

E2) National and Organizational Culture: A set of norms, behaviors, beliefs, customs and values shared by an independent nation. (Helena Almedia \& Bernard Sequira, 2019) Organizational culture is defined as beliefs, assumptions, values, and modes of interaction that lead to the unique social and psychological environment of an organization (Daniel Denison, 2000).

E3) Social Challenges: Each society is faced with a variety of deviations and problems that are detrimental to its society, culture, growth, and degeneration, with detrimental effects on its community development process (Hasan Rafiei, 1977). Traffic, unemployment, air and soil pollution crisis, polarization and class divisions in society, elite migration, urban renewal, etc. are some of the social challenges in Iran. (Saeed Madani; Marwah Wamaghi, 1979)

E4) Intellectual Property Rights: refers to rights that give its owners the right to benefit from human intellectual and innovative activities and have economic value and the ability to trade, but are not subject to a specific material object (Seyyed Hossein Safai, 2003).

\section{(F) Environmental factors:}

F1) Environmental challenges:The environment is a set of energy sources, inanimate substances (water, soil and air) and living things (plants, animals and humans) that are interconnected. The main precondition for environmental protection is to establish a balance among its constituents. (Mohammad Reza Imani, 2004) At present, the most important environmental challenges in Iran are air pollution, water scarcity and pollution, climate change, waste, food contamination. And transportation, noise, oil pollution, deforestation, soil erosion and biodiversity. (Research Center for Environmental Research, Iran University of Medical Sciences, 2016).

F2) energy consumption:Due to the increasing energy consumption in the production and use of cars, the scarcity of natural resources, the move towards sustainable development and environmental protection should be avoided as much as possible. The following are some of the scientific and practical activities: (Esmaeil Fatehifar, Saeid Paknia, 2014) 


\section{Conclusion}

The Iranian automobile industry has faced many failures since its inception. The onset of the storm in the early forties and the production of world-class products, followed by the revolution and the imposed war, the failure to lay down grand strategies and problems such as sanctions have left the Iranian auto industry behind in competition in the world auto industry. . Although automakers have had some success in automotive segmentation and assembly from the bodybuilding, color and assembly stages, but due to lack of proper and effective technology transfer, only the production and assembly of products that have been designed and researched. And the development of these products is done by foreign companies and there is no transfer of knowledge based technologies. To achieve the right position, quantitatively or qualitatively, the Iranian automobile industry can rely on the conceptual model presented in this paper by foresight approach to each of the economic, social, political and environmental factors in the future. Soft and hard technology achieves success. Each of these factors include parameters that, if taken into consideration, can provide a clear horizon for the Iranian automotive industry, otherwise the heel of the automotive industry will continue to rotate over the same forty years and continue to produce low-quality products and services. Undesirable ability to compete in the automotive industry in the world and will not satisfy consumers.

Consideration of fourth generation futurism includes soft technology futures (automotive innovation, research and development, industry relationship with university and knowledge based institutions, technical knowledge, management systems, knowledge management and training, processes and systems). Future of hard technology (machinery, tools, equipment and hardware and computers and product life cycle), political factors (political relations with countries, sanctions and war conditions and technology transfer tendency), economic factors (foreign direct investment) Keywords: Policies, Structural Changes in the Economy of Iran and the World, Effective Government Support, Market and Customer Attention N), social factors (human capital, national and organizational culture, social challenges and intellectual property rights) and environmental factors (environmental challenges and energy consumption) make the Iranian automobile industry have a say in the global competition. 


\section{References}

Aghajani, Hasan Ali, Farzadfar, Ramin, (2013). Comparative Study of Technology Transfer Models. Rules of Evaluation and Identification of Knowledge Base Companies, Vice President of Science and Technology

Akbarpour, Narges, Abdi, Nariman, (2015). Technology Transfer Methods in Iranian Automotive Industry

Ashouri, Hojjat, Seyed Hosseini, Seyed Mohammad, Radfar, Reza (2016). Management Futures Research Quarterly, Winter 2016, Model of Technology Transfer with Future Research Approach in Rail Transport Industry (Case Study: Express Train)

Cunningham, James A O'Reilly, Paul, (2018) Macro, meso and micro perspectives of technology transfer 25Lorenz ,Annika, Raven, Michael, Blind, Knut,2017, The role of standardization at the interface of product and process development in biotechnology

Esmaeilzadeh, Zeinab, Noroozi Ghormak, Hediyeh, Mohseni Zenozi, Seyyed Jamaleddin, (2016). Comparison of the Impact of Import Replacement Strategy and Endogenous Development Strategy on Regional Sustainable Development

Geoing, Jin, (2016). Technology Growth Magazine Soft Technology and Fourth Generation Technology Futures

Hamzehpour, Mehdi, Khatibi, Alireza, (2019).Soft Technology Global Technology Transformation, Imam Sadegh University Press

Khalil, Tariq, (2002). Technology Management, Power Technology Center Publications (Text)

Majlis Research Center, January (2015). Pathology of the Automotive Industry of Iran and Providing Solutions to Existing Challenges to the General Policies of Resistance Economics (Research Project)

Mirsalim, Seyed Mostafa, (2016). ISNA News Agency, National Motor Research Center

Mousi Khani, Morteza, Gharakhani, Davood, (2013). Quarterly Journal of Development and Change Management, Identification and Ranking of Factors Affecting Technology Transfer Using MADM Techniques

Marashi, Mojgan, Abdolvand, Neda, (2018). Technology Growth Quarterly, Summer. Providing a Model for Technology Transfer Governance and Cloud Computing

Martin ,Cheryl, Leurent ,Helena, (2017). Technology and Innovation for the Future of Production: Accelerating Value Creation

Mosleh Shirazi, Ali, Mohammadi, Ali, Abbasi, Abbas, Nazari ,Mohammad, (2016). Soft Commercial Technology and its Transfer Model in Small and Medium Enterprises: A Review

Mazurkiewicz ,Adam, Poteralska ,Beata (2017). Technology Transfer Barriers and Challenges Faced by R\&D Organisations

Nazimi, Amir, Aristocracy, Mojdeh, Azmadian, Mahdiyeh, (2016). National Foresight Program Secretariat, Spring 2016, Typology of National Foresight Plans, Supporting Future Plans Report Series.

Schot, Johan, Steinmueller, Edward, (2018). Three frames for innovation policy: R\&D, systems of innovation and transformative Changemeng Tze, Lee, Muthusamy, Kanesan, Soft Technology Transfer for Japanese MNCs in Malaysia Conceptual Model

Sadat, Mohammad Ali, (2003). Investigation of Iranian Automobile Industry.Middle East Bank Economic Research Group, January 2015, Iranian Automobile Industry Survey. Getting to Know Iranian Technology and Innovation Management Activists and Specialists, Iranian Technology Management Association. 
Seed Sprayer, Mehrdad, Babakhan, Alireza, Gholamian, Mohammad Reza, Pourmosgari, Majid, (Fall 2015). Application of Fuzzy Theory in Prioritizing Technology Transfer Methods in Iran (Case Study: Iran Power Plant Industry)

Shafi'i Ardestani, Sonya et al., (2008). UNIDO Technology Futures Handbook, Defense Industry Research Institute Automotive Industry Analysis, Saderat Bank of Iran, July.

Shojaee Fard, Mohammad Hassan (2014). Euro Standards for Automotive and Domestic Car Evaluation, Fuel Consumption Conference Ministry of Industry and Mining Publications, samt Newspaper, Website www.oica.net

Samali Kaskon, Asadi, Mahmood, Letter of Culture No. 55, (2013). Management Gaps of Production of Science in Iran

Takakuwa ,Soemon, Vez ,Ivica, (2017). Technology Transfer and World Competitiveness

Wang, Xin, Duan, Yibing, (2010). Identifying Core Technology Structure of Electric Vehicle Industry through Patent Co-citation Information 